\title{
UNEMPLOYMENT EFFECTS OF GREENFIELD AND BROWNFIELD INVESTMENTS IN POST-TRANSITION EUROPEAN UNION MEMBERS
}

\section{Yilmaz Bayar', Rita Remeikiené2, Jan Žufan ${ }^{3}$, Miloslav Novotný4 $^{4}$}

\footnotetext{
1 Usak University, Faculty of Economics and Administrative Sciences, Department of Economics, Turkey, ORCID: 0000-0002-6776-6524, yilmaz.bayar@usak.edu.tr;

2 Mykolas Romeris University, Public Security Academy, Lithuania, ORCID: 0000-0002-3369-485X, rita.remeikiene@mruni.eu;

University College of Business in Prague, Czech Republic, ORCID: 0000-0001-9031-5791, zufan@vso-praha.eu;

4 Brno University of Technology, Faculty of Civil Engineering, Institute of Building Structures, Czech Republic, ORCID: 0000-0001-8248-1466, novotny.m2@fce.vutbr.cz.
}

\begin{abstract}
International direct and portfolio investments have gone up considerably as of mid-1980s. The foreign direct investments with characteristic of long term horizon may affect the economic variables through know-how and technology transfer, physical capital expansion, and new job creation. However, foreign direct investments may have potential to negatively affect the domestic competitors with insufficient competitiveness in the industry. So, the economic effects of FDI inflows have been one of the much-debated and studied issues in the international economics. This study investigates the unemployment effects of greenfield and brownfield investments in 11 posttransition EU members over 2003-2017 period through panel cointegration and causality tests. The article fills the gap in the literature, because the relevant empirical literature has generally researched the impact of total FDI flows on the unemployment/employment. The empirical findings revealed that brownfield investments raised the unemployment in overall panel in the long run, but greenfield investments had no significant impacts on the unemployment in overall panel in the long run. However, greenfield investments decreased the unemployment in Croatia, Hungary, and Slovenia, and raised the unemployment in Poland and Slovakia, while brownfield investments raised the unemployment only in Czechia. Consequently, it is not very reasonable to compare our findings with the results of other studies using total FDI inflows as the independent variable. But, it is generally consistent with theoretical and empirical expectations.
\end{abstract}

Keywords: Greenfield investments, brownfield investments, unemployment, panel cointegration, causality analyses.

JEL Classification: C33, E24, F21, F23.

APA Style Citation: Bayar, Y., Remeikienè, R., Žufan, J., \& Novotný, M. (2020). Unemployment Effects of Greenfield and Brownfield Investments in Post-transition European Union Members. E\&M Economics and Management, 23(2), 4-16. https://doi.org/10.15240/tul/001/2020-2-001

\section{Introduction}

The foreign direct investment (FDI) inflows have exhibited substantial increases with contribution of relaxation of the impediments over the international flows of goods, services and capital mainly resulting from the accelerating liberalization and globalization as of 1980s. Consequently, international FDI inflows reached USD 3.111 trillion in 2007, but then contracted due to economic crises and the increasing protectionism concerns in the recent years and became USD 1.95 trillion in 2017 (World Bank, 2019a). 
The rapidly expanding FDI flows made the economic effects of FDI one of the muchdiscussed and studied topics in the international economics. On the one hand, the scholars have focused on the effect of FDI inflows on the economic growth, unemployment, total taxes, technological development, environmental degradation (see, e.g., Lasbrey et al., 2018). On the other side, the determinants of FDI attraction have been investigated evenly considering its positive economic effects (see, e.g., Tocar, 2018). In this study, we researched the unemployment effects of greenfield and brownfield investments to fill the gap in the relevant literature, because the relevant empirical literature has generally researched the impact of total FDI flows on the unemployment/employment. But however, FDI can be implemented in two different ways such as greenfield investment or brownfield investment. The greenfield investment is the FDI type in which direct investors make a new plant, distribution plant or shop in the host country. But the direct investors make investment in or take over an operating company in case of brownfield investment (Galeza \& Chan, 2015). Therefore, the interaction mechanisms among greenfield investment, brownfield investment, and unemployment may differ depending on the FDI type.

The effect of FDI inflows on the unemployment depends on job creating capacity of FDI inflows. In this regard, greenfield investments are theoretically expected to decrease the unemployment, because the greenfield investment includes building the new plants, distribution plants and facilities and in turn creating new jobs. However, greenfield investments also can raise the unemployment in case the similar domestic firms cannot compete with the foreign competitors in terms of technological level, know-how, and production scale and terminate their activities. However, the greenfield investments are quite likely expected to decrease the unemployment. On the other side the effect of brownfield investments, in other words mergers and acquisitions on the unemployment depend on the direct investor's behavior. Hence, the direct investor can make a contribution to the firm enlargement and in turn create new jobs. On the contrary, the direct investors can raise the unemployment by technology and know-how transfer, and productivity improvements. Consequently, net effect of brownfield investment on the unemployment is highly unclear.

The EU transition economies went through a process of institutional and economic transformation as of late 1980s and then respectively integrated with global economy and the EU (European Union). The FDI inflows to the EU transition economies raised considerably during 2003-2007 period especially together with EU membership/membership negotiations and reached about USD 153.4 billion in 2007, but then experienced significant contractions due to the recent economic crises and was about USD 27.4 billion in 2017 (World Bank, 2019a).

The main aim of the article is to investigate the unemployment effects of greenfield and brownfield investments in EU transition economies. The article contributes to the relevant literature twofold. First, the nearly all the empirical studies examining the economic effects of FDI inflows have generally used the variable of total FDI inflows in the analyses. So our paper will be one of the early studies investigating the unemployment effects of two main types of FDI inflows separately, in other words greenfield investment and brownfield investments. Secondly, the empirical studies generally have employed regression analysis, cointegration and causality analyses disregarding structural breaks, although FDI inflows and the main macroeconomic variables have been influenced seriously by the crisis periods. The Westerlund and Edgerton (2008) cointegration test used in the empirical analysis regards not only the structural break in the study period, but also cross-sectional dependence, and heterogeneity.

The remainder of the paper is structured as follows. The next section provides a brief conceptual background of the subject with the literature review. Data and methods used in examining the unemployment effects of greenfield and brownfield investments are described in Section 2. Section 3 provides and discusses the results, while last part of the paper concludes with direction for further research.

\section{Literature Review}

The significant increases in international FDI flows have led the researchers to investigate the economic effects of FDI flows such as FDI impact on economic growth, unemployment, 
technological development, competitiveness, financial sector development, tax revenues, and environmental degradation. In this research, we focused on the unemployment effects of FDI inflows considering the gap in the relevant empirical literature. The relevant empirical literature was summarized in Tab. 1 regarding the extensive number of studies about FDIemployment/unemployment nexus. The relevant empirical literature revealed that the impact of FDI inflows on the unemployment has stayed inconclusive in keeping with theoretical considerations.

In the relevant empirical literature Çiftçioğlu et al. (2007), Balcerzak and Zurek (2011), Carp (2012), Strat et al. (2015), Zdravković et al. (2017), Dritsakis and Stamatiou (2018) and Ali et al. (2018) researched the nexus FDIunemployment for the country/countries from our sample, and the studies also reached mixed findings. For example, Çiftçioğlu et al. (2007) revealed that FDI raised the unemployment, while Balcerzak and Zurek (2011), Carp (2012) and Dritsakis and Stamatiou (2018) discovered that FDI decreased the unemployment, but Zdravković et al. (2017) revealed no significant effects of FDI on the unemployment. The links between unemployment and other macroeconomic indicators has also been studied by Sasongo and Huruta (2019).

Furthermore, nearly all the empirical studies investigating the economic effects of FDI inflows have used total FDI inflows in the econometric analyses without making any separation between greenfield and brownfield investments, although both FDI types may have different economic implications depending on the industry attracting the FDI flows. The study researches the effect of greenfield and brownfield investments on the unemployment regarding the gap in the literature and the relevant theoretical considerations.

\section{Tab. 1: $\quad$ Literature summary - Part 1}

\begin{tabular}{|c|c|c|c|}
\hline Study & $\begin{array}{l}\text { Country/Country } \\
\text { group and period }\end{array}$ & Method & $\begin{array}{c}\text { Impact of FDI } \\
\text { on unemployment }\end{array}$ \\
\hline Seyf (2000) & $\begin{array}{l}\text { France, Germany, } \\
\text { Spain, UK, } 1994\end{array}$ & Regression & No significant effects \\
\hline Chang (2005) & Taiwan, 1981-2003 & VAR analysis & No significant effects \\
\hline Craigwell (2006) & $\begin{array}{l}20 \text { Caribbean } \\
\text { countries, 1990-2000 }\end{array}$ & Panel data analysis & Negative \\
\hline Çiftçioğlu et al. (2007) & $\begin{array}{l}9 \text { Central and Eastern } \\
\text { European countries, } \\
\text { 1995-2003 }\end{array}$ & Regression analysis & Positive \\
\hline $\begin{array}{l}\text { Jayaraman and Singh } \\
(2007)\end{array}$ & Fiji, 1970-2003 & $\begin{array}{l}\text { Cointegration and } \\
\text { causality analyses }\end{array}$ & Negative \\
\hline Lin and Wang (2008) & $\begin{array}{l}52 \text { industrialized/ } \\
\text { developing countries, } \\
2000-2004\end{array}$ & Regression analysis & $\begin{array}{l}\text { Negative in developing } \\
\text { countries; } \\
\text { No significant effects in } \\
\text { industrialized countries }\end{array}$ \\
\hline Rizvi and Nishat (2009) & $\begin{array}{l}\text { Pakistan, India and } \\
\text { China, 1985-2008 }\end{array}$ & Panel data analysis & No significant impact \\
\hline Subramaniam (2009) & Malaysia, 1975-2004 & Cointegration analysis & No significant effects \\
\hline Aktar et al. (2009) & Turkey, 2001-2007 & VAR analysis & No significant effects \\
\hline Karlsson et al. (2009) & China, 1998-2004 & Time series analysis & Negative \\
\hline Pinn et al. (2011) & Malaysia,1970-2007 & $\begin{array}{l}\text { ARDL cointegration } \\
\text { and causality tests }\end{array}$ & $\begin{array}{l}\text { One-way causality } \\
\text { from FDI to } \\
\text { employment }\end{array}$ \\
\hline Palát (2011) & Japan, 1983-2009 & Regression analysis & Negative \\
\hline
\end{tabular}




\section{Tab. 1: $\quad$ Literature summary - Part 2}

\begin{tabular}{|c|c|c|c|}
\hline Study & $\begin{array}{l}\text { Country/Country } \\
\text { group and period }\end{array}$ & Method & $\begin{array}{c}\text { Impact of FDI } \\
\text { on unemployment }\end{array}$ \\
\hline Balcerzak and Zurek (2011) & Poland, 1995-2009 & VAR analysis & Negative \\
\hline Carp (2012) & Romania, 1991-2010 & Regression & Negative \\
\hline Yayli and Deger (2012) & $\begin{array}{l}27 \text { developing } \\
\text { countries, 1991-2008 }\end{array}$ & Causality analysis & $\begin{array}{l}\text { One-way causality } \\
\text { from FDI to } \\
\text { employment }\end{array}$ \\
\hline Shaari et al. (2012) & Malaysia, 1980-2010 & Regression & Negative \\
\hline Mehra (2013) & India, 1970-2007 & Regression & Negative \\
\hline Mucuk and Demirsel (2013) & $\begin{array}{l}7 \text { develoing countries, } \\
1981-2009\end{array}$ & Panel data analysis & $\begin{array}{l}\text { Positive in Turkey } \\
\text { and Argentina; } \\
\text { Negative in Thailand; } \\
\text { No significant effects } \\
\text { in Colombia, Chile, } \\
\text { Philippines, and } \\
\text { Uruguay }\end{array}$ \\
\hline Habib and Sarwar (2013) & Pakistan,1970-2011 & Cointegration analysis & Negative \\
\hline Zeb et al. (2014) & Pakistan, 1995-2011 & Regression & Negative \\
\hline Jaouadi (2014) & $\begin{array}{l}\text { Saudi } \\
\text { Arabia,1991-2012 }\end{array}$ & Cointegration analysis & Positive \\
\hline Bayar (2014) & Turkey, 2000-2013 & ARDL cointegration & Positive \\
\hline Schmerer (2014) & $\begin{array}{l}19 \text { OECD countries, } \\
1980-2003\end{array}$ & Regression analysis & Negative \\
\hline $\begin{array}{l}\text { Stamatiou and Dritsakis } \\
(2014)\end{array}$ & Greece, 1970-2012 & ARDL cointegration & No significant effects \\
\hline Kurtovic et al. (2015) & $\begin{array}{l}6 \text { Western Balkan } \\
\text { countries, 1998-2012 }\end{array}$ & $\begin{array}{l}\text { Pedroni and } \\
\text { Fisher-Johansson } \\
\text { cointegration tests and } \\
\text { Granger causality test }\end{array}$ & Negative \\
\hline $\begin{array}{l}\text { Djambaska and Lozanoska } \\
(2015)\end{array}$ & $\begin{array}{l}\text { Macedonia, } \\
1999-2013\end{array}$ & Regression & No significant effects \\
\hline Strat et al. (2015) & $\begin{array}{l}13 \text { last EU member } \\
\text { countries, 1991-2012 }\end{array}$ & Causality analysis & $\begin{array}{l}\text { One-way causality } \\
\text { from FDI to } \\
\text { unemployment } \\
\text { in } 4 \text { countries; } \\
\text { One-way causality } \\
\text { from unemployment to } \\
\text { FDI in } 3 \text { countries; } \\
\text { No significant causality } \\
\text { in } 6 \text { countries }\end{array}$ \\
\hline Haddad (2016) & Jordan, 1998-2015 & Regression analysis & Negative \\
\hline Irpan et al. (2016) & Malaysia,1980-2012 & ARDL cointegration & Negative \\
\hline Chella and Phiri (2017) & \begin{tabular}{|l} 
South Africa, \\
1970-2014
\end{tabular} & ARDL cointegration & No significant effects \\
\hline Nikoloski (2017) & \begin{tabular}{|l|} 
Macedonia, \\
2009-2015
\end{tabular} & Regression analysis & Negative \\
\hline
\end{tabular}




\begin{tabular}{|c|c|c|c|}
\hline Study & $\begin{array}{l}\text { Country/Country } \\
\text { group and period }\end{array}$ & Method & $\begin{array}{c}\text { Impact of FDI } \\
\text { on unemployment }\end{array}$ \\
\hline Bayar and Şaşmaz (2017) & $\begin{array}{l}21 \text { emerging } \\
\text { economies, } \\
1994-2014\end{array}$ & Cointegration analysis & Positive \\
\hline Yildirim and Yildirim (2017) & Turkey, 2005-2016 & VAR analysis & Negative \\
\hline Zdravković et. al (2017) & $\begin{array}{l}17 \text { transition } \\
\text { economies, } \\
2000-2014\end{array}$ & Panel cointegration & No significant effects \\
\hline $\begin{array}{l}\text { Onanuga and Onanuga } \\
\text { (2018) }\end{array}$ & $\begin{array}{l}23 \text { emerging } \\
\text { economies, } \\
1991-2016\end{array}$ & Regression analysis & Negative \\
\hline Mohamed (2018) & Sudan, 1990-2016 & $\begin{array}{l}\text { VAR and causality } \\
\text { analyses }\end{array}$ & No significant effects \\
\hline $\begin{array}{l}\text { Dritsakis and Stamatiou } \\
(2018)\end{array}$ & $\begin{array}{l}15 \text { EU members, } \\
\text { 1970-2015 }\end{array}$ & Causality analysis & Negative \\
\hline Nguyen (2019) & $\begin{array}{l}5 \text { central Asian } \\
\text { countries, 1997-2016 }\end{array}$ & Cointegration analysis & Negative \\
\hline
\end{tabular}

\section{Aim, Data and Econometric Methodology}

The article's empirical aim is to investigate the unemployment effects of greenfield and brownfield investments in 11 EU transition economies during the 2003-2017 period by panel cointegration and causality analyses.

\subsection{Main Statistical Variables}

The dependent variable of unemployment as percent of total labor force was extracted from World Bank (2019a). On the other side, greenfield and brownfield investments were provided from the database of UNCTAD and included in the model as a percent of GDP. All the variables were annual. The presence of greenfield and brownfield investments' data led us to determine the study period as 2003-2017.

The sample of the econometric analysis consisted of Bulgaria, Croatia, Czechia, Estonia, Hungary, Latvia, Lithuania, Poland, Romania, Slovakia and Slovenia. The econometric analyses were implemented through the software of Stata 14.0 and Gauss 10.0. The main characteristics of the dataset were shown in Tab. 3. The average employment was about $9.5 \%$ in the sample, but varied considerably from country to the country. The average greenfield investment was about $4.4 \%$ of GDP in the sample and the average brownfield investment was about $0.55 \%$ of GDP in the sample. However, all greenfield and brownfield investments also changed significantly among the countries.

\section{Tab. 2: Data description}

\begin{tabular}{l|l|l}
\multicolumn{1}{c|}{ Variables } & \multicolumn{1}{c|}{ Description } & \multicolumn{1}{c}{ Source } \\
\hline UNEMP & Unemployment, total (\% of total labor force) & World Bank (2019a) \\
\hline GFDI & Greenfield investments $(\%$ of GDP) & UNCTAD (2019) \\
\hline BFDI & Brownfield investments (\% of GDP) & UNCTAD (2019) \\
\hline
\end{tabular}




\begin{tabular}{l|l|c|l|c}
\multicolumn{1}{c|}{ Variables } & Mean & Std. deviation & Minimum & Maximum \\
\hline UNEMP & 9.578691 & 3.706703 & 2.89 & 19.482 \\
\hline GFDI & 4.390562 & 5.323532 & 0.0189589 & 45.1763 \\
\hline BFDI & 0.5580028 & 1.206754 & -0.8189105 & 8.607166 \\
\hline
\end{tabular}

Source: own

\subsection{Econometric Methodology}

Westerlund and Edgerton (2008) cointegration test was derived from the unit root test of Schmidt and Phillips (1992), Ahn (1993), and Amsler and Lee (1995) rests on Lagrange Multiplier (LM). The test takes notice of not only cross-sectional dependence and structural break, but also heteroscedasticity and serial correlation. The cointegration Formula is expressed as following:

$$
\begin{aligned}
& y_{i, t}=\alpha_{i}+\eta_{i} t+\delta_{i} D_{i, t}+x_{i, t}^{\prime} \beta_{i}+ \\
& +\left(D_{i, t} x_{i, t}\right)^{\prime} \gamma_{i}+z_{i, t} \\
& x_{i, t}=x_{i, t-1}+w_{i, t}
\end{aligned}
$$

where $i=1,2, \ldots, N$ indicates the crosssections and $t=1,2, \ldots, T$ indicates the time dimension of the dataset. $D_{i, t}$ dummy variable in (1) numbered Formula is defined in (3) numbered Formula. Furthermore, $\alpha_{i}$ and $\beta_{i}$ respectively denotes the constant and slope coefficients before the structural breaks, and $\gamma_{i}$ and denotes the ones after structural breaks. Finally, $w_{i, t}$ represent the error term.

$$
D_{i, t}= \begin{cases}1, & t>T_{i} \\ 0, & \text { Other }\end{cases}
$$

$z_{i, t}$ error term is derived the following Formulas allowing the cross-sectional dependence. $F_{t}$ and $F_{j, t}$ shows the common vector with $\mathrm{k}$ dimesions, $\lambda_{i}$ represents the the compatible vector of factor loadings. $F_{t}$ is stationary under the assumption of $p_{j}<1$ for all the js. Thereby (1) numbered Formula is cointegrated under the condition of $\emptyset_{i}<0$.

$$
\begin{aligned}
& z_{i, t}=\lambda_{i}^{\prime} F_{t}+v_{i, t} \\
& F_{j, t}=\rho_{j} F_{j, t-1}+u_{j, t}
\end{aligned}
$$

$$
\emptyset_{i}(L) \Delta v_{i, t}=\emptyset_{i} v_{i, t-1}+e_{i, t}
$$

$\hat{S}_{i, t}$ is calculated as the following in case of cross-sectional dependence:

$$
\begin{aligned}
& \hat{S}_{i, t}=y_{i, t}-\hat{\eta}_{i} t-\hat{\delta}_{i} D_{i, t}+x_{i, t}^{\prime} \hat{\beta}_{i}+ \\
& +\left(D_{i, t} x_{i, t}\right)^{\prime} \hat{\gamma}_{i}-\lambda_{i}^{\prime} \hat{F}_{t} \\
& \Delta \hat{S}_{i, t}=\text { constant }+\emptyset_{i} \hat{S}_{i, t-1}+ \\
& +\sum_{j=1}^{p_{i}} \emptyset_{i} \Delta \hat{S}_{i, t-j}+\text { error term }
\end{aligned}
$$

Lastly, the standardized test statistics of Westerlund and Edgerton (2008) cointegration test are calculated as in (9-10) Formulas. $\widehat{\emptyset}_{i}$ is the OLS estimation of $\emptyset_{i}$ in (8) numbered Formula and $\hat{\sigma}_{i}$ is the estimated standard error. Further, $\widehat{w}_{i}$ is the estimated long term variance of $\Delta v_{i, t} \cdot S E\left(\widehat{\emptyset}_{i}\right)$ is the estimated standard error of $\widehat{\emptyset}_{i}$. The refusal of the null hypothesis suggesting the cointegration relationship among the variables showed the existence of the cointegrating relationship among the variables.

$$
\begin{aligned}
& Z_{\emptyset}(N)=\sqrt{N}\left(\overline{L M}_{\emptyset}(N)-E\left(B_{\emptyset}\right)\right) \\
& Z_{\tau}(N)=\sqrt{N}\left(\overline{L M}_{\tau}(N)-E\left(B_{\tau}\right)\right) \\
& L M_{\varnothing}(i)=T \widehat{\emptyset}_{i}\left(\widehat{\widehat{w}}_{i}\right) \\
& L M_{\tau}(i)=\frac{\widehat{\phi}_{i}}{\operatorname{SE}\left(\widehat{\phi}_{i}\right)}
\end{aligned}
$$

The slope coefficients of the cointegration Formula was estimated by AMG (augmented mean group) estimator of Eberhardt and Bond (2009). The AMG estimator calculates both cross-sectional coefficients and panel coefficients and also provides more reliable results than CCE (Common Corelated Effects) estimator of Pesaran (2006) does, because it estimates the panel cointegration coefficient 
by weighting the arithmetic average of the cross-sectional cointegration coefficients. Furthermore, the AMG estimator takes notice of the dynamic effects and common factors in the series and also yields the efficient results for the unbalanced panels. The estimator also can be used in case endogeneity problem (see Eberhardt \& Bond, 2009; Eberhardt \& Teali, 2011 for detailed information about the estimator). Lastly, the causal interaction among greenfield investment, brownfield investment, and unemployment is tested with Dumitrescu and Hurlin (2012) causality test, a modified version of traditional Granger causality test for heterogeneous models and also yields robust results in case of cross-sectional dependence.

\section{Empirical Analysis}

In the applied section of the paper, first crosssectional dependence was tested with LM CD test of Pesaran (2004) taking notice of dataset's time and cross-section dimensions and the test consequences were shown in Tab. 4. The null hypothesis suggesting the cross-sectional independence was denied at $1 \%$ significance level. So the tests pointed out the presence of cross-sectional dependence among three series.

Secondly, slope coefficients' homogeneity was tested with adjusted delta tilde test of Pesaran and Yamagata (2008) and test consequences were shown in Tab. 5 . The null hypothesis suggesting the existence of

\section{Tab. 4: Results of cross-sectional dependency tests}

\begin{tabular}{l|c|c}
\multicolumn{1}{c|}{ Test } & Test statistic & P-value \\
\hline LM (Breusch \& Pagan, 1980) & 281.7 & 0.0000 \\
\hline LM adj. (Pesaran et al., 2008) & 41.66 & 0.0000 \\
\hline LM CD & 15.82 & 0.0000 \\
\hline
\end{tabular}

Source: own based on cross-sectional dependence tests

\section{Tab. 5: Results of homogeneity tests}

\begin{tabular}{l|c|c}
\multicolumn{1}{c|}{ Tests } & Test statistic & P-value \\
\hline$\tilde{\Delta}$ & -1.391 & 0.918 \\
\hline$\tilde{\Delta}_{a d j .}$ & -1.606 & 0.946 \\
\hline
\end{tabular}

Source: own based on homogeneity tests

\section{Tab. 6: Results of CIPS unit root test}

\begin{tabular}{l|l|c}
\multicolumn{1}{c|}{ Variables } & \multicolumn{1}{c|}{ Constant } & Constant + trend \\
\hline UNEMP & $-1.316(0.094)^{\star}$ & $0.070(0.528)$ \\
\hline D(UNEMP) & $-1.262(0.004)^{\star \star *}$ & $-0.308(0.079)^{\star}$ \\
\hline GFDI & $-2.438(0.007)^{\star * *}$ & $-0.042(0.483)$ \\
\hline D(FDI) & $-4.093(0.000)^{\star \star *}$ & $-3.144(0.001)^{\star * *}$ \\
\hline BFDI & $-1.173(0.120)$ & $-0.520(0.302)$ \\
\hline$D(F D I)$ & $-3.339(0.000)^{\star * *}$ & $-1.554(0.050)^{\star *}$ \\
\hline
\end{tabular}

Source: own based on panel unit root test

Note: Optimum lag length was specified as 1 taking notice of Schwarz and Hannan-Quinn information criterion. ${ }^{* * *}$, ${ }^{* *},{ }^{*}$ indicated that it is respectively significant at $1 \%, 5 \%$, and $10 \%$. 
homogeneity was accepted in the light of $p$-values of both tests. So the slope coefficients of the cointegration Formula were homogenous.

The presence of unit root in the series was examined with Pesaran (2007) CIPS (Crosssectionally augmented IPS (Im, Pesaran, \& Shin, 2003)) unit root test taking notice of cross-sectional dependence and the test consequences were shown in Tab. 6. The test consequences revealed that all the series were I(1).

The long run unemployment effect of greenfield and brownfield investments were tested by Westerlund and Edgerton (2008) cointegration test considering the crises in the study period and the presence of cross-sectional dependence and the test consequences were shown in Tab. 7. The null hypothesis suggesting no cointegration relationship among the series was rejected in all the three models. So a significant cointegration relationship among greenfield investment, brownfield investment, and unemployment in the light of test results.
The dates of structural breaks determined endogenously by the test revealed the recent crises.

The cointegration coefficients was estimated by AMG estimator taking notice of cross-sectional dependence and the test consequences were shown in Tab. 8. The test consequences revealed that brownfield investments positively affected the unemployment in overall panel, but greenfield investments had no significant effects on the unemployment in overall panel. However, the individual coefficients revealed that greenfield investments decreased the unemployment in Croatia, Hungary, and Slovenia, but raised the unemployment only in Slovakia. On the other side, brownfield investments raised the unemployment only in Czechia.

All the EU transition countries attracted much more greenfield investments than brownfield investments during the study period. However, greenfield investments had a decreasing effect on the unemployment only in Croatia, Hungary,

\section{Tab. 7: Results of cointegration test}

\begin{tabular}{|c|c|c|c|c|}
\hline Model & $Z \varphi(N)$ & P-value & $Z_{\tau}(N)$ & P-value \\
\hline No shift & -2.230 & 0.013 & -2.806 & 0.003 \\
\hline Level shift & 0.173 & 0.049 & -1.816 & 0.035 \\
\hline Regime shift & 1.121 & 0.024 & 0.040 & 0.016 \\
\hline Country & \multicolumn{2}{|c|}{ Level shift } & \multicolumn{2}{|c|}{ Regime shift } \\
\hline Bulgaria & \multicolumn{2}{|c|}{2015} & \multicolumn{2}{|c|}{2015} \\
\hline Croatia & \multicolumn{2}{|c|}{2015} & \multicolumn{2}{|c|}{2015} \\
\hline Czechia & \multicolumn{2}{|c|}{2005} & \multicolumn{2}{|c|}{2014} \\
\hline Estonia & \multicolumn{2}{|c|}{2004} & \multicolumn{2}{|c|}{2004} \\
\hline Hungary & \multicolumn{2}{|c|}{2014} & \multicolumn{2}{|c|}{2014} \\
\hline Latvia & \multicolumn{2}{|c|}{2009} & \multicolumn{2}{|c|}{2009} \\
\hline Lithuania & \multicolumn{2}{|c|}{2011} & \multicolumn{2}{|c|}{2011} \\
\hline Poland & \multicolumn{2}{|c|}{2011} & \multicolumn{2}{|c|}{2012} \\
\hline Romania & \multicolumn{2}{|c|}{2012} & \multicolumn{2}{|c|}{2012} \\
\hline Slovakia & \multicolumn{2}{|c|}{2012} & \multicolumn{2}{|c|}{2012} \\
\hline Slovenia & \multicolumn{2}{|c|}{2012} & \multicolumn{2}{|c|}{2014} \\
\hline
\end{tabular}

Source: own based on panel cointegration test

Note: The information criterion by Bai and $\mathrm{Ng}$ (2004) was utilized in specification of the common factors and determined 5 as maximum. Westerlund and Edgerton (2008) followed the method suggested by Bai and Perron (1998) for determination of structural breaks. 


\section{Tab. 8: Results of cointegration coefficients' estimation}

\begin{tabular}{l|c|c}
\multirow{2}{*}{ Countries } & \multicolumn{2}{c}{ Coefficients } \\
\cline { 2 - 3 } & GFDI & BFDI \\
\hline Bulgaria & 0.0069215 & 0.0446915 \\
\hline Croatia & $-1.47446^{* * *}$ & -0.3603813 \\
\hline Czechia & 4.133843 & $0.456585^{\star *}$ \\
\hline Estonia & -0.0798053 & 0.8744853 \\
\hline Hungary & $-0.480004^{*}$ & 1.168243 \\
\hline Latvia & -0.1367851 & 3.289604 \\
\hline Lithuania & 0.127508 & -0.2796247 \\
\hline Poland & $2.348943^{* * *}$ & -0.9850148 \\
\hline Romania & 0.0370108 & 0.1674633 \\
\hline Slovakia & $0.2818848^{* * *}$ & 1.898311 \\
\hline Slovenia & $-0.6352004^{* *}$ & 1.061451 \\
\hline Panel & 0.3754415 & $\mathbf{0 . 6 6 6 8 9 2 1}$ \\
\hline
\end{tabular}

Source: own based on cointegration coefficients' estimation

Note: ${ }^{* *},{ }^{* *},{ }^{*}$ indicated that it is respectively significant at $1 \%, 5 \%$, and $10 \%$.

and Slovenia, but raised the unemployment in Poland and Slovakia and no significant effects in the rest of the countries. However, brownfield investments raised the unemployment in the panel considering the panel homogeneity. The brownfield investments generally have been realized as mergers and acquisitions in the EU and this process inevitably raised the unemployment. We evaluate that full labor mobility in the EU had influence on the effect of both greenfield and brownfield investments on the unemployment.
On the other side, all the empirical studies conducted for the country/countries in our sample used total FDI inflows and did not research the effect of greenfield and brownfield investments on the unemployment separately. In this regard, it is not very much meaningful to compare our findings with the results of other studies. However, the aforementioned empirical studies also have stayed inconclusive about the employment/unemployment effect of the FDI inflows in the countries. For example, Çiftçioğlu et al. (2007) revealed that FDI raised the unemployment, Balcerzak and Zurek (2011),

Tab. 9:

Results of causality test

\begin{tabular}{|c|c|c|c|}
\hline Null Hypothesis & W-Stat. & Zbar-Stat. & Prob. \\
\hline DGFDI $\nrightarrow$ DUNEMP & 2.03690 & -0.59174 & 0.5540 \\
\hline DUNEMP $\nrightarrow$ DGFDI & 5.24624 & 1.89692 & 0.0578 \\
\hline DBFDI $\nrightarrow$ DUNEMP & 3.26906 & 0.36373 & 0.7161 \\
\hline DUNEMP $\nrightarrow$ DBFDI & 2.27400 & -0.40788 & 0.6834 \\
\hline DBFDI $\rightarrow$ DGFDI & 8.69262 & 4.56939 & 5.E-06 \\
\hline DGFDI $\rightarrow$ DBFDI & 5.38393 & 2.00369 & 0.0451 \\
\hline
\end{tabular}


Carp (2012) and Dritsakis and Stamatiou (2018) revealed a decreasing effect of FDI inflows on the unemployment, but Zdravković et al. (2017) revealed no significant effects of FDI on the unemployment.

The causal interplay between greenfield investments, brownfield investments, and unemployment was tested by Dumitrescu and Hurlin (2012) causality test and test consequences were shown in Tab. 9. Test consequences revealed a one-way causality from unemployment to greenfield investment, and a two-way causality between brownfield investment and greenfield investment. So both greenfield and brown field investments had no significant effects on the unemployment in the short run, but unemployment had a significant effect on the unemployment and also there was a mutual interaction between greenfield and brownfield investments.

\section{Conclusions}

Rapidly raising foreign direct investments together with international portfolio investments have come to the forefront as one of the main features of the third globalization wave since 1980s. However, the countries with different development levels also have experienced significant contractions in FDI flows mainly resulting from the economic and political crises. The significant hikes in FDI flows encouraged the researches to explore the economic effects of FDI flows. In this regard, we detected that most of the studies examining the economic effects of FDI flows have broadly employed total FDI inflows, although two main types of FDI flows (greenfield and brownfield investments) have significant features in nature and in turn yield different economic consequences. Furthermore, the empirical studies generally disregarded the crises in the study period, while FDI flows and the other macroeconomic variables were seriously affected by the crises. Therefore, we research the unemployment effect of greenfield and brownfield investments for the sample of EU transition economies in both short and long term through second generation panel cointegration test regarding structural break and causality analysis.

The cointegration analysis revealed that greenfield investments had no significant effects on the unemployment in overall panel in the long run. However, the individual coefficients revealed that greenfield investments decreased the unemployment in Croatia, Hungary, and Slovenia, but raised the unemployment only in Slovakia. The cointegration analysis results showed that only Croatia, Hungary, and Slovenia experienced the decreasing unemployment effect of greenfield investments in the long run, although the FDI inflows to the EU transition economies have been generally in form of greenfield investment. So, the job creating capacity of the greenfield investments was found to be significant only in a few countries. It can be possibly resulted from full labor mobility in $\mathrm{EU}$ or that the similar domestic firms cannot to compete with the foreign competitors in terms of technological level, know-how, and production scale and terminate their activities. On the other side, the panel coefficient revealed that brownfield investments positively affected the unemployment in overall panel. But individual coefficients disclosed that brownfield investments raised the unemployment only in Czechia. The brownfield investments has potential to raise the unemployment through technology and know-how transfer, and productivity improvements. So our finding is consistent with the theoretical considerations.

Consequently, it is not very reasonable to compare our findings with the results of the other studies using total FDI inflows as the independent variable. But, the findings are generally consistent with theoretical and empirical expectations. The ambiguity related to the employment effects of FDI flows mainly stems from the variable and selection of analysis method. Further studies can be conducted on unemployment effects of greenfield or brownfield investments on sectoral basis, because the sector structure (labor intensive or capital intensive) is also critical for FDI-unemployment nexus. Stakeholders or institutions responsible for unemployment reduction have to pay attention towards investment to ensure that available resources are attractive enough to attract greenfield and brownfield investments at any conditions. How do make the attractiveness for foreign investments more favorable? First of all, to make easier financing at a subsidized interest rate, because high costs of borrowing reduce the opportunity for FDI. The second, to lower the administration/tax burden for employment possibilities. 


\section{References}

Ahn, S. K. (1993). Some tests for unit roots in autoregressive-integrated-moving average models with deterministic trends. Biometrica, 80(4), 855-868. https://doi.org/10.1093/ biomet/80.4.855

Aktar, I., Demirci, N., \& Öztürk, L. (2009). Can unemployment be cured by economic growth and foreign direct investment? SÜ iiBF Sosyal ve Ekonomik Araştırmalar Dergisi, 17(2), 453-467.

Ali, U., Shan, W., Wang, J.-J., \& Amin, A. (2018). Outward Foreign Direct Investment and Economic Growth in China: Evidence from Asymmetric ARDL Approach. Journal of Business Economics and Management, 19(5), 706-721. https://doi.org/10.3846/ jbem.2018.6263

Amsler, C., \& Lee, J. (1995). An LM test for a unit root in the presence of a structural change. Econometric Theory, 11(2), 359-368. https://doi.org/10.1017/S026646660000921X

Bai, J., \& Ng, S. (2004). A Panic attack on unit roots and cointegration. Econometrica, 72(4), 1127-1177. https://doi.org/10.1111/ j.1468-0262.2004.00528.x

Bai, J., \& Perron, P. (1998). Estimating and testing linear models with multiple structural changes. Econometrica, 66(1), 47-78. https://doi.org/10.2307/2998540

Balcerzak, A. P., \& Zurek, M. (2011). Foreign direct investment and unemployment: VAR analysis for Poland in the years 1995-2009. European Research Studies, 14(1), 3-14.

Bayar, Y. (2014). Effects of economic growth, export and foreign direct investment inflows on unemployment in Turkey. Investment Management and Financial Innovations, 11(2), 20-27.

Bayar, Y., \& Şaşmaz, M. Ü. (2017). Impact of foreign direct investments on unemployment in emerging market economies: A co-integration analysis. International Journal of Business and Economic Sciences Applied Research, 10(3), 90-96.

Breusch, T. S., \& Pagan, A. R. (1980). The Lagrange Multiplier Test and its Applications to Model Specification in Econometrics. Review of Economic Studies, 47(1), 239-253. https://doi. org/10.2307/2297111

Carp, L. (2012). The impact of FDI on the labor market in central and eastern Europe during the international crisis. Review of Applied Socio-Economic Research, 3(1), 43-54.
Chang, S. C. (2005). The dynamic interactions among foreign direct investment, economic growth, exports and unemployment: Evidence from Taiwan. Economic Change and Restructuring, 38(3-4), 235-256. https://doi. org/10.1007/s10644-006-9005-x

Chella, N., \& Phiri, A. (2017). Long-run cointegration between foreign direct investment, direct investment and unemployment in South Africa (MPRA Paper No. 82371). Retrieved March 3, 2019, from https://mpra.ub.unimuenchen.de/82371/

Craigwell, R. (2006). Foreign direct investment and employment in the English and Dutch-speaking Caribbean (Tripartite Caribbean Employment Forum Working Papers). Retrieved March 3, 2019, from https://www.ilo.org/wcmsp5/groups/public/--americas/---ro-lima/---sro-port_of_spain/ documents/meetingdocument/wcms_306245.pdf

Çiftcioglu, S., Fethi, S., \& Begovic, N. (2007). The impact of net inflows of foreign direct investment on economic growth, unemployment and openness: A panel data analysis of nine central and east European countries. Journal of Global Business Management, 3(2), 89-94.

Djambaska, E., \& Lozanoska, A. (2015). Foreign direct investment and unemployment: Evidence from the Republic of Macedonia. International Journal of Economics, Commerce and Management, 3(12), 73-85.

Dritsakis, N., \& Stamatiou, P. (2018). Causal nexus between FDI, exports, unemployment and economic growth for the old European Union members: Evidence from panel data. International Journal of Economic Sciences, 7(2), 35-56. https://doi.org/10.20472/ ES.2018.7.2.002

Dumitrescu, E., \& Hurlin, C. (2012). Testing for Granger non-causality in heterogeneous panels. Economic Modelling, 29(4), 1450-1460. https://doi.org/10.1016/j.econmod.2012.02.014

Eberhardt, M., \& Bond, S. (2009). Crosssection dependence in nonstationary panel models: A novel estimator (MPRA Paper). Munich: Munich University. Retrieved February 26, 2019, from https://mpra.ub.uni-muenchen. de/17870/

Eberhardt, M., \& Teali, F. (2011). Econometrics for grumblers: A new look at the literature on cross-country growth empirics. Journal of Economic Surveys, 25(1), 109-155. https://doi.org/10.1111/j.14676419.2010.00624.x 
Galeza, T., \& Chan, J. (2015). What is direct investment? Finance \& Development, 52(3), 34-35.

Habib, M. D., \& Sarwar, S. (2013). Impact of foreign direct investment on employment level in Pakistan: A time series analysis. Journal of Law, Policy and Globalization, 10, 46-55.

Haddad, A. (2016). Analysis of foreign direct investment and unemployment and their impact on economic growth in Jordan. International Journal of Investment Management and Financial Innovations, 2(1), 1-12.

Im, K. S., Pesaran, M. H., \& Shin, Y. (2003). Testing for unit roots in heterogeneous panels. Journal of Econometrics, 115(1), 53-74. https://doi.org/10.1016/S0304-4076(03)00092-7

Irpan, H., Saad, R., Nor, A., Noor, A., \& Ibrahim, N. (2016). Impact of foreign direct investment on the unemployment rate in Malaysia. Journal of Physics: Conference Series, 710, 1-10. https://doi.org/10.1088/17426596/710/1/012028

Jaouadi, S. (2014). Could foreign direct investment increase unemployment: Case of KSA. Research Journal of Economics and Business Studies, 3(9), 51-56.

Jayaraman, T. K., \& Singh, B. (2007). Foreign direct investment and employment creation in Pacific Island countries: An empirical study of Fiji (Working Paper Series, No. 35). Bangkok: Asia-Pacific Research and Training Network on Trade. Retrieved from https://www.unescap.org/sites/default/files/ AWP\%20No.\%2035.pdf

Karlsson, S., Lundin, N., Sjöholm, F., \& He, P. (2009). Foreign firms and Chinese employment. World Economy, 32(1), 178-201. https://doi. org/10.1111/j.1467-9701.2009.01162.x

Kurtovic, S., Siljkovic, B., \& Milanovic, M. (2015). Long-term impact of foreign direct investment on reduction of unemployment: Panel data analysis of the Western Balkans countries. Journal of Applied Economics and Business Research, 5(2), 112-129.

Lasbrey, A., Enyoghasim, M., Tobechi, A., Uwajumogu, N., Chukwu, B., \& Kennedy, O. (2018). Foreign direct investment and economic growth: Literature from 1980 to 2018. International Journal of Economics and Financial Issues, 8(5), 309-318.

Lin, M., \& Wang, Y. (2008). Capital outflow and unemployment: Evidence from panel data. Applied Economic Letters, 15(14), 1135-1139. https://doi.org/10.1080/13504850600993655
Mehra, N. (2013). Impact of foreign direct investment on employment and gross domestic product in India. International Journal of Economics and Research, 4(4), 29-38.

Mohamed, O. A. S. (2018). Vector autoregressive analysis - VAR foreign direct investment and unemployment: Sudan, 1990-2016. Global Journal of Economics and Business, 4(2), 224-235.

Mucuk, M., \& Demirsel, M. T. (2013). The effect of foreign direct investment on unemployment: Evidence from panel data for seven developing countries. Journal of Business, Economics and Finance, 2(3), 53-66.

Nikoloski, D. (2017). The impact of foreign direct investments on employment: The case of the Macedonian manufacturing sector. Eastern Journal of European Studies, 8(2), 147-165.

Nguyen, A. T. (2019). The relationship between economic growth, foreign direct investment and unemployment in central Asia: A vector autoregressive model approach. Journal of Contemporary Economic and Business Issues, 6(1), 5-19.

Onanuga, A. T., \& Onanuga, O. T. (2018). Government policy, foreign direct investment and unemployment in emerging economies. Acta Universitatis Danubius. OEconomica, 14(2), 21-40.

Palát, M. (2011). The impact of foreign direct investment on unemployment in Japan. Acta Univerisitatis Agriculturae et Silviculturae Mendelianae Brunensis, 59(7), 261-266. https://doi.org/10.11118/actaun201159070261

Pesaran, M. H. (2004). General Diagnostic Tests for Cross Section Dependence in Panels (Discussion Paper No. 1240). Bonn: IZA. Retrieved from http://ftp.iza.org/dp1240.pdf

Pesaran, M. H. (2006). Estimation and inference in large heterogeneous panels with a multi factor error structure. Econometrica, 74(4), 967-1012. https://doi.org/10.1111/j.14680262.2006.00692.x

Pesaran, M. H. (2007). A simple panel unit root test in the presence of cross-section dependence. Journal of Applied Econometrics, 22(2), 265-312. https://doi.org/10.1002/jae.951

Pesaran, M. H., \& Yamagata, T. (2008). Testing slope homogeneity in large panels. Journal of Econometrics, 142(1), 50-93. https://doi.org/10.1016/j.jeconom.2007.05.010

Pesaran, M. H., Ullah, A., \& Yamagata, T. (2008). A bias-Adjusted LM test of error crosssection independence. Econometrics Journal, 
11(1), 105-127. https://doi.org/10.1111/j.1368423X.2007.00227.x

Pinn, S. L. S., Ching, K. S., Kogid, M., Mulok, D., Mansur, K., \& Loganathan, N. (2011). Empirical analysis of employment and foreign direct investment in Malaysia: An ARDL bounds testing approach to cointegration. Advances in Management \& Applied Economics, 1(3), 77-91.

Rizvi, S. Z. A., \& Nishat, M. (2009). The impact of foreign direct investment on employment opportunities: Panel data analysis: Empirical evidence from Pakistan, India and China. Pakistan Development Review, 48(4), 841-851.

Sasongko, G., \& Huruta, A. D. (2019). The causality between inflation and unemployment: the Indonesian evidence. Business: Theory and Practice, 20, 1-10. https://doi.org/10.3846/ btp. 2019.01

Schmerer, H.-J. (2014). Foreign direct investment and search unemployment: Theory and evidence. International Review of Economics and Finance, 30, 41-56. https://doi. org/10.1016/j.iref.2013.11.002

Schmidt, P., \& Phillips, P. C. B. (1992). LM tests for a unit root in the presence of deterministic trends. Oxford Bulletin of Economics and Statistics, 54(3), 257-287. https://doi.org/10.1111/j.1468-0084.1992. tb00002.x

Seyf, A. (2000). Can more FDI solve the problem of unemployment in the EU? A short note. Applied Economics Letters, 7(2), 125-128. https://doi.org/10.1080/135048500351951

Shaari, M. S., Hussain, N. E., \& Halim, M. S. B. A. (2012). The impact of foreign direct investment on the unemployment rate and economic growth in Malaysia. Journal of Applied Sciences Research, 8(9), 4900-4906.

Stamatiou, P., \& Dritsakis, N. (2014). The impact of foreign direct investment on the unemployment rate and economic growth in Greece: A time series analysis. Proceedings of International Work-Conference on Time Series Analysis (ITISE), Granada, Spain, 1 (pp. 97-108).
Strat, V. A., Davidescu-Alexandru, A., \& Paul-Vass, A. M. (2015). FDI and the unemployment - A causality analysis for the latest EU members. Procedia Economics and Finance, 23, 635-643. https://doi.org/10.1016/ S2212-5671(15)00448-7

Subramaniam, T. (2009). The dynamic interactions among foreign direct investment, unemployment, economic growth and exports: Evidence from Malaysia. Jati, 13, 35-48.

Tocar, S. (2018). Determinants of foreign direct investment: A review. Review of Economic and Business Studies, 11(1), 165-196. https:// doi.org/10.1515/rebs-2018-0069

UNCTAD. (2019). World Investment Report: Annex Tables. Retrieved April 20, 2019, from https://unctad.org/en/Pages/DIAE/World\%20 Investment\%20Report/Annex-Tables.aspx

Westerlund, J., \& Edgerton, D. (2008). Simple tests for cointegration in dependent panels with structural breaks. Oxford Bulletin of Economics and Statistics, 70(5), 665-704. https://doi. org/10.1111/j.1468-0084.2008.00513.x

World Bank. (2019a). Foreign direct investment, net inflows (BoP, current US\$). Retrieved May 20, 2019, from https://data. worldbank.org/indicator/BX.KLT.DINV.CD.WD

Yaylı, S., \& Değer, M. K. (2012). The relationships between foreign direct investments and employment: Dynamic panel data causality analysis on developing countries (1991-2008). Finans, Politik ve Ekonomik Yorumlar, 49(568), 43-52.

Yildirim, M., \& Yildirim, A. (2017). The influence of consumption and investment on unemployment in Turkey: A SVAR approach. Ekonomika, 96(1), 74-92. https://doi. org/10.15388/Ekon.2017.1.10665

Zdravković,A., Đukić, M., \&Bradić-Martinović, A. (2017). Impact of FDI on unemployment in transition countries: Panel cointegration approach. Industrija, 45(1), 161-174. https://doi. org/10.5937/industrija45-13548

Zeb, N., Qiang, F., \& Sharif, M. S. (2014). Foreign direct investment and unemployment reduction in Pakistan. International Journal of Economics and Research, 5(2), 10-17. 